\title{
MENUMBUHKAN KESADARAN ORANG TUA DALAM MENANAMKAN NILAI MORALANAK USIA DINI MELALUI PARENTING EDUCATION
}

\author{
Muammar Qadafi \\ Universitas Islam Negeri Mataram, Nusa Tenggara Barat \\ mqadafi31@uinmataram.ac.id
}

\begin{abstract}
Parenting education is a very important activity that should be implemented in early childhood education institutions. This activity is an opportunity for teachers to provide enthusiasm and foster awareness of parents to be involved in children's education. This research is a qualitative research with a case study approach carried out at RA Tiara Chandra Yogyakarta. The purpose of this study is to find out how parenting education was carried out in this school and how was the benefits to the develop parents' awareness to succeed of the program of developing moral values of children. The results of the study showed that parenting education was carried out routinely in the form of training in living values education and monthly parenting to provide refreshment and evaluate programs that have been implemented. There were three groups of activities that had been carried out, namely education, involvement, and empowerment of parents. Parental involvement in developing children's moral values had a significant impact on children's awareness to live up to moral values in their dailylife.
\end{abstract}

Keywords: parenting education, moral values, early childhood

\begin{abstract}
Abstrak
Parenting education merupakan kegiatan yang sangat penting untuk dilaksanakan di lembagan pendidikan anak usia dini. Kegiatan ini menjadi kesempatan bagi para guru untuk memberikan semangat dan menumbuhkan kesadaran orang tua untuk terlibat dalam pendidikan anak. Penelitian ini adalah penelitian kualitatif dengan pendekatan studikasus yang dilaksanakan di RATiara Chandra Yogyakarta. Tujuan dari penelitian ini adalah untuk mengetahui bagaimana parenting education dilaksanakan di sekolah ini dan sejauh mana manfaatnya terhadap munculnya kesadaran orang tua dalam mensukseskan program penanaman nilai moral pada anak. Hasil penelitian menunjukkan bahwa parenting education dilaksanakan secara rutin dalam bentuk pelatihan living values education dan parenting bulanan untuk memberikan penyegaran dan mengevaluasi programprogram yang telah didilaksanakan. Terdapat tiga kelompok kegiatan yang telah dilakukan, yaitu
\end{abstract}


pendidikan, pelibatan, dan pemberdayaan orang tua. Keterlibatan orang tua terhadap penanaman nilai moral anak memberikan dampak yang signifikan terhadap kesadaran anak untuk menghidupkan nilai moral dalamkehidupan sehari-hari.

Kata Kunci: parenting education, nilai moral, anak usia dini

\section{PENDAHULUAN}

Pendidikan anak usia dini adalah usaha sadar yang dilakukan oleh orang-orang dewasa, baik dilembagapendidikan formalmaupun tidak formal dalam mengembangkan seluruh aspek perkembangan anak. Pendidikan anak yang baik tentu saja akan memberikan dampak yang baik terhadap keberlangsungan hidup anak di masamasa yang akan datang. Kostelnik dalam bukunya menyatakan bahwa anak yang memiliki pengalaman yang positif memiliki fondasi yang kuat untuk kesuksesan hidup berikutnya. Sebaliknya, anak yang memiliki pengalaman yang buruk cenderung mendapatkan bantuan remedial ekstensif, menemui masalah kesehatan mental, mengalami kegagaralan akademis, atau drop out dari sekolah (Kostelnik, dkk., 2015:2).

Usia dini merupakan waktu yang sangat tepat untuk memberikan pengalaman yang positif kepada anak melaluipenanaman nilai-nilai moral. Secara umum orang-orang memandang bahwa keluarga adalah guru pertama dan sumber pendidikan karakter yang paling utama bagi anak. Sebelum memulai pendidikan di PAUD, mereka lebih dahulumendapatkan pendidikan bersama orang tua dan akan terus dilalui selama bertahun-tahun. Jika di sekolah guru dapat berubah-ubah karena berbagai faktor, maka di rumah mereka akan selalu bersama dengan orang tua yang sama.

Salah satu faktor yang menentukan kesuksesan penanaman nilai-nilai karakter anak adalah kerjasama yang baik antara guru dan orang tua. Kerjasama ini dapat berupa keterlibatan orang tua dalam berbagai kegiatan yang dilakukan oleh guru di sekolah dan dilanjutkan ketika berada di rumah. Menurut Lickona, meskipun sekolah mampu meningkatkan pemahaman awal para siswanya ketika berada di sekolah, dan terbukti bahwa mereka mampu melaksanakan hal tersebut. Sikap-sikap baik yang dimiliki oleh anak akan perlahan menghilang jika tidak mendapatkan dukungan dari lingkungan keluarga di rumah (Lickona, 2015:57).

Melibatkan orang tua dalam berbagai kegiatan, baik di sekolah maupun di rumah bukanlah perkara yang mudah. Sebagian besar orang tua memilikipandangan bahwa pendidikan anak adalah tugasnya guru di sekolah dan mereka hanya memberikan dukungan berupa pembiayaan dan kebutuhan fasilitas untuk menunjang pendidikan anak. Dalam sebuah wawancara, kepala sekolah RATiara Chandra menyampaikan bahwa pada saat mendaftarkan anak di sekolah orang tua sebagian besar memilih fullday school agar mereka tidak perlu memikirkan anak saat bekerja. Mereka benarbenar menyerahkan dan mempercayakan anaknya sepenuhnya di sekolah dan bersedia membayar biaya yang dibebankan kepada mereka (wawancara pada tanggal)

Pemahaman orang tua tentang pendidikan anak seperti ini tentu saja merupakan kekeliruan yang sangat besar. Terlebih lagi jika berbicara 
tentang penanaman nilai moral pada anak, keterlibatan orang tua merupakan sebuah keniscayaan karena pendidikan moral di sekolah tidak akan memberikan dampak yang besar jika tidak dilanjutkan oleh orang tua ketika berada di rumah. Oleh sebab itu, pengelola lembaga PAUDharus memberikan edukasi kepada orang tua agar memiliki kesadaran dan merasa berkewajiban untuk terlibat aktif dalam pendidikan anak.

Menurut penelitian yang dilakukan oleh Mega dan Pramesti, keterlibatan orang tua dalam pendidikan anak memberikan manfaat yang sangat baik. Selain memberikan manfaat secara langsung kepada anak, orang tua juga pada dasarnya mendapatkan manfaat bagi diri mereka sendiri. Beberapa manfaat dari keterlibatan orang tua antara lain: anak mendapatkan treatment yang tepat sesuai dengan kebutuhannya, orang tua merasa terfasilitasi untuk menunaikan kewajibannya, orang tua mendapatkan tambahan pengetahuan terkait pendidikan anak, orang tua bisa berbagi pengalaman dan pengetahuan baru kepada anak, dan hubungan orang tua dan anak akan semakin dekat.

Penelitian lain yang dilakukan oleh Heru dan Risdianto

Mengingat pentingnya peran orang tua dalam pendidikan anak, khususnya pendidikan moral, kepala sekolah RA Tiara Chandra memiliki inisiatif untuk memberikan kesadaran kepada orang tua dalam menanamkan nilai moral kepada anak melalui parenting education. Kepala sekolah meyakini bahwa pendidikan di sekolah tidak boleh berakhir di sekolah, tetapi harus berlanjut ketika anak berada di lingkungan keluarga dan masyarakat, sehingga anak mendapatkan pendidikan yang berkesinambungan selama 24 jam.

\section{PEMBAHASAN}

\section{Pendidikan Moral di RA Tiara Chandra Yogyakarta}

RA Tiara Chandra merupakan salah satu sekolah yang mengedepankan pendidikan berbasis moral. Motivasi ini muncul karena dilatar belakangi oleh pengalama pahit kepala sekolah di masa kecil yang merasa trauma terhadap sikap kasar seorang guru terhadap dirinya. Rasa trauma itu masih terus menghantui hidupnya sampaisaat ini, sehingga dia termotivasi untuk mendirikan sekolah yang ramah terhadap anak dan menjadikan nilai moral sebagai salah satu keunggulan.

Untuk mewujudkan sekolah yang berbasis pada nilai moral, kepala sekolah mulai membangun komitmen terhadap diri sendiri untuk menjadi pribadi yang selalu memberikan contoh yang baik terhadap guru, karyawan, orang tua, dan anak. Kemudian virus kebaikan itu mulai ditularkan kepada guru, karyawan, dan orang tua, sehingga semua orang dewasa yang berada di sekeliling anak dapat menjadi contoh yang baik bagi anak itu sendiri. Hal ini seperti yang disampaikan oleh kepala sekolah RATiara Chandra, bahwa membangun nilai moral itu butuh proses yang lama, tidak hanya bergantung pada anak, tetapi juga butuh komitmen dari guru, karyawan, orang tua, dan masyarakat untuk menciptakan lingkungan yang baik bagi anak.

Orang-orang dewasa yang berada di sekitar anak merupakan kunci kesuksesan pendidikan moral bagi anak. Jika orang-orang dewasa 
mampu menjadi role model yang baik bagi anak, maka anak pasti akan meniru perilaku-perilaku baik tersebut. Namun, orang-orang dewasa belum sepenuhnya konsisten untuk melakukan hal-hal baik di hadapan anak. Berbagai persoalan yang dihadapi sering kali membuat perasaan tidak nyaman, sakit hati, emosional, dan berbagai perilaku buruk lainnya. Oleh sebab itu, kepala sekolah secara rutin mengadakan pelatihan living values education untuk para guru dan pegawai yang dilatih langsung oleh Dr. Muqowin, pelatih nasionalyang juga merupakan akademisi di UIN Sunan Kalijaga Yogyakarta. Setelah berjalan dengan baik, pelatihan mulai melibatkan orang tua siswa, guru-guru dari sekolah lain, dan kedepannya akan melibatkan masyarakat secara umum.

Living values education adalah program pendidikan nilai-nilai. Program ini menyajikan berbagai macam aktivitas pengalaman dan metodologi praktis bagipara guru dan fasilitator untuk membantu anak-anak dan para remaja mengeksplorasi dan mengembangkan nilai-nilai kunci pribadi dan sosial: Kedamaian, Penghargaan, Cinta, Tanggung Jawab, Kebahagiaan, Kerjasama, Kejujuran, Kerendahan hati, Toleransi, Kesederhanaan, dan Persatuan. Terdapat pula segmen khusus untuk para orangtua dan pengasuh, juga bagi para pengungsi dan anak-anak korban perang (Tillman, 2004: x).

Salah satu hal yang menjadikan pelatihan LVE ini menarik bagi kepala sekolah adalah adanya usaha untuk memberikan kesadaran kepada peserta untuk mengimplementasikan nilai-nilai kebaikan dalam kehidupan nyata. Peserta tidak hanya disuguhi konsep dan teoriteori semata, tetap langsung mempraktikkan dan menginternalisasi nilai-nilai dalamkehidupan sehari-hari. Tentu saja ini menjadi hal yang penting karena proses pembelajaran anak adalah dengan meniru apa yang biasa mereka dengar dan lihat dari orang-orang dewasa yang ada di sekirar mereka.

\section{Nilai Moral yang Ditanamkan kepada Anak}

Moral adalah suatu keyakinan tentang benar atau salah, baik atau buruk, yang mendasari tindakan atau pemikiran yang sesuai dengan hukum yang berlaku dan kesepakatan sosial (Ibung, 2009: 56). Guru di RATiara Chandra secara konsisten menanamkan nilai-nilai moral kepada anak yang diadopsi dari nilai-nilai universal dan budaya lokal.

Beberapa nilai yang selama ini telah dikenalkan dan ditanamkan kepada anak antara lain: kedamaian, penghargaan, cinta, tanggung jawab, kebahagiaan, kerjasama/gotong royong, kejujuran, kerendahan hati, kesederhanaan, saling berbagi, keberanian, dan tolong menolong.

Pada praktiknya, nilai-nilaimoral tersebut diejawantahkan dalam bentuk aktivitas yang sesuaidengan usia anak. Misalnya, nilai tanggung jawab diwujudkan dalam bentuk mengembalikan barang-barang sentra pada tempatnya, membersihkan lantai yang sudah dikotori, mengembalikan pensil teman setelah dipinjam, mengakui kesalahan, menyampaikan amanah guru yang harus disampaikan kepada orang tua, dll.

\section{Implementasi Parenting Education dan di RA Tiara Chandra Yogyakarta}

Parenting education adalah program dukungan yang ditujukan kepada para orang tua atau anggota keluarga yang lain agar semakin memilikikemampuandalammelaksanakanfungsi 
sosial dan pendidikan dalam hal mengasuh, merawat, melindungi, dan mendidik anaknya di rumah sehingga anak dapat tumbuh dan berkembang secara optima sesuai dengan usia dan tahap perkembangannya (Kemendiknas, 2011).

Manfaat kegiatatan parenting adalah untuk membangun komunikasi yang baik antara lembaga dengan orangtua. Sehingga pola pengasuhan yang dijalankan di lembaga dengan yang diterapkan orang tua dirumah selaras. Melalui kegiatan parenting juga orangtua dapat mengetahui capaian perkembangan anak, hakhak dasar apa saja yang harus dipenuhi orangtua dalam kelangsungan hidup anak, dan memberikan pengetahuankepada orangtua.

Program parenting di RA Tiara Chandra dilaksanakan secara rutin setiap bulan dengan berbagai tema dan agenda yang bervariasi. Tetapi memiliki tujuan yang sama, yaitu untuk memberikan informasi, pengetahuan, dan menyatukan persepsiterkait dengan pendidikan anak. Sehingga, pendidikan anak di sekolah dan di rumah dapat selaras dan berkesinambungan.

Terdapat tiga kelompok kegiatan parenting yang biasa dilakukan, yaitu:pendidikan untuk orang tua, pelibatan orang tua, dan pemberdayaan orang tua. Pendidikan untuk orang tua adalah pembekalan terkait dengan tumbuh kembang dan pendidikan anak. Pelibatan orang tua adalah pola pemberian pengalaman kepada orang tua tentang apa dan bagaimana anak belajar.Pemberdayaan orang tua adalah mengoptimalkan peran orang tua dalam pembelajaran dan pengasuhan anakdi rumah (Kemendiknas, 2012).

Salah satu program parenting yang paling sering dilaksanakan di RATiara Chandra adalah terkait dengan penanaman nilai moral pada anak.
Orang tua diberikan pelatihan LVE yang bertujuan untuk memberikan kesadaran menghidupkan nilai-nilai moral kepada orang tua, sehingga orang tua dapat menjadi role model bagi anak ketika berada di rumah. Tujuan dari pelatihan ini juga adalah untuk meningkatkan kesadaran dan partisipasi orang tua terhadap kegiatan-kegiatan pendidikan yang dilaksanakan sekolah, diantaranya adalah program pendidikan moral.

Kepala sekolah menyampaikan bahwa program pelatihan LVE ini sudah berjalan sejak tahun 2010 dan secara rutin dilakukan minimal satu kali dalam satu tahun. Pada tahap pertama, pelatihan ini dilaksanakan untuk guru-guru dan karyawan di sekolah, selanjutnya untuk guruguru di sekolah lain, kemudian dilaksanakan untuk orang tua siswa dan masyarakat umum.

Pelatihan LVEinidinilai sangat efektif dalam mengubah cara pandang orang tua terhadap pendidikan moral anak. Menginternalisasi nilainilai moral pada anak tidak bisa dilakukan dengan cara memberitahu dan menceramahi saja, tetapi yang paling penting adalah memberikan contoh secara langsung karena salah satu karakteristik anak adalah suka meniru apa saja yang dicontohkan oleh orang-orang dewasa yang ada di sekitarnya.

Melalui pelatihan iniOrang tua menjadi lebih aktif dan memilikikesadaran menghidupkan nilainilai moral dan pada akhirnya berimplikasi terhadap anak ketika berada di rumah. Orang tua tidak lagimenjadi banyak berbicara konsepkonsep kebaikan, menceritakan kisah-kisah kebaikan dari para tokoh tertentu, tetapi secara langsung menjadi sosok orang baik yang secara nyata dilihat oleh anak dalam kehidupan seharihari. 
Selain itu, orang tua menjadi lebih aktif mengikuti berbagai kegiatan yang dicanangkan oleh guru-guru di sekolah. Daintara kegiatan tersebut adalah penggalangan dana untuk mengadakan pasar sembako murah bagi warga kurang mampu. Kegiatan ini memberikan pengalaman bagiorang tua dan anak tentang nilai berbagi, kerjasama, kasih sayang, tolong menolong, simpati, dll.

Selain pelatihan LVE yang dilaksanakan sekali setahun bersama trainer nasional, sekolah juga mengadakan kegiatan parenting setiap bulan untuk memberikan refreshment terhadap kegiatan pelatihan yang telah dilakukan. Hal ini penting untuk selalu memberikan penguatan dan evaluasi dari program-program yang telah dicanangkan.

Pada kegiatan parenting bulanan ini, guru selalu mengingatkan kembali program-program yang dilaksanakan di sekolah dan menjadi kesepakatan bersama untuk pendidikan moral anak. Pada kegiatan ini juga dapat menjadi kesempatan bagi orang tua untuk menceritakan masalah-masalah yang dihadapi dalam pengasuhan anak ketika berada di rumah.

Salah satu guru menyampaikan bahwa kegiatan parenting bulanan biasanya menjadi kesempatan untuk mengevaluasi programprogram yang telah dilaksanakan bersama orang tua siswa. Kesempatan ini juga digunakan untuk mengontrol sejauh mana orang tua secara konsisten melaksanakan program-program tersebut ketika berada di rumah.

Salah satu program yang dikontrol adalah penggunaan kartu anak hebat ketika berada di rumah. Sebagian besar orang tua memiliki kesadaran dan konsisten mengunduh dan menempel kartu-kartu tersebut, dan beberapa orang masih kurang konsisten karena berbagai alasan.

\section{Peran Orang Tua dalam Penanaman Nilai Moral Anak}

Penanaman nilai moral pada anak merupakan program utama pemerintah yang dituangkan dalam bentuk kurikulum di sekolah. Salah satu kompetensi yang harus dimiliki oleh siswa PAUD adalah kompetensi sikap, baik sikap spiritual, maupun sosial.

Orang tua merupakan madrasah pertama bagi anak dan selamanya akan menjadi pengasuh, pendidik, dan contoh utama bagi anak. Brooks menyampaikan bahwa orang tua adalah individu-individu yang mengasuh, melindungi, dan membimbing dari bayi hingga tahap dewasa. Mereka harus memberikan tanggung jawab dan perhatian kepada anak yang mencakup kasih sayang dan pendidikan moral (Brooks, 2011:10).

Melalui program parenting education berupa pelatihan LVE, RA Tiara Chandra menyadari bahwa keterlibatan orang tua adalah sebuah keharusan dalam mensukseskan program pendidikan moral bagi anak.

Orang tua tidak dapat sepenuhnya mempercayakan pendidikan anak kepada sekolah karena hakikatnya peran orang tua sebagai pendidik adalah fitrah dan tidak dapat digantikan oleh siapapun. Sehingga, kesibukan orang tua untuk mencari nafkah tidak boleh menjadi alasan untuk melepas tanggung jawab utama sebagai pendidik anak ketika di rumah.

Dari hasil wawancara dengan kepala sekolah, RATiara Chandra telah mencanangkan program yang melibatkan orang tua dalam pendidikan moral anak. Diantara kegiatan 
tersebut adalah kegiatan flea market. Kegiatan ini adalah kegiatan pasar murah yang melibatkan orang tua dan anak. Mereka diminta untuk menyiapkan barang-barang bekas layak pakai, dan sejumlah sembako dan bekerjasama membagikan dan menjual barang-barang tersebut kepada masyarakat kurang mampu yang ada disekitar lokasi tersebut. Pada saat kegiatan, orang tua dan anak harus bekerjasama untuk menghidupkan nilaimoraldan menebar kebaikan kepada setiappembeli.

Selain itu, orang tua juga diminta untuk mengunduh kartu anak hebat yang secara rutin diunggah di media sosial yang dikelola oleh sekolah. Kartu anak hebat berisikan nilai-nilai moral dan beberapa implementasi dari nilai tersebut yang diambil dari hasil refleksi siswa itu sendiri. Misalnya implementasidarinilaitanggung jawab menurut siswa adalah mengembalikan pensil milik teman. Kartu ini dapat dicetak dan ditempel di berbagai tempat sebagai pengingat dan kesepakatan bahwa hari itu antara orang tua dan anak harus menghidupkan nilai tersebut dalam setiap aktivitas. Pada saat ada yang melanggar, maka mereka harus saling mengingatkan kesepakatan sesuai yang tertera di dalamkartu tersebut.

Penggunaan kartu anak hebat ini menjadi kontrol bagi orang tua ketika berada di rumah, sehingga program penanaman nilai yang diterapkan di sekolahdapat terus berlanjut ketika berada di rumah dan anak dapat merasakan hidup dalam nilai-nilai moral selama 24 jam.

Setiap tahun, RA Tiara Chandra melaksanakan kegitan graduation day, yaitu hari kelulusan siswa dan dilaksanakannya pentas seni berbasis nilai-nilai moral. Pada kegiatan ini, orang tua diundang dan sebagian dilibatkan untuk menjadi peserta. Terdapat beberapa penampilan berbasis nilai-nilai moral, yaitu bermain peran, drama kolosal, menari, bernyanyi, dan membaca puisi.

Kegiatan-kegiatan yang melibatkan orang tua tersebut memang dirancang atas dasar kesadaran bahwa pendidikan moral anak tidak akan berjalan dengan baik tanpa adanya kerjasama antara guru di sekolah dan orang tua di rumah. Kepala sekolah menyampaikan bahwa orang tua tidak semuanya memiliki kesadaran dan hal itu sangat berimplikasi terhadap perkembangan moral anak. Beberapa orang tua yang sangat aktif mengikuti programprogram sekolah, pasti merasakan sendiri perubahan-perubahan yang terjadi pada anak, begitu juga sebaliknya, orang tua yang kurang aktif akan merasakan kondisi yang tidak banyak berbeda dari sebelumnya.

Hal ini dapat dilihat dari hasil wawancara dengan salah satu orang tua siswa yang telah menitipkan anaknya selama dua tahun di RA Tiara Chandra. Dia menyampaikan bahwa anaknya mengalami perubahan yang sangat signifikan jika dibandingkan dengan dua tahun yang lalu. Saat ini, proses internalisasi nilai-nilai moral sudah sangat dirasakan. Anaknya setiap hari selalu meminta agar bekalnya dilebihkan untuk dimakan bersama dengan teman-teman lainnya. Saat berada di rumah, anaknya selalu mengingatkan jika melihat hal-hal yang kurang tepat dilakukan oleh orang tua. Misalanya, saat orang tua membuang sampah sembarangan, makan dengan tangan kiri, minum sambil berdiri, berbohong atau melanggar kesepakatan, dll. 


\section{PENUTUP}

Parenting Education adalah salah satu program yang harus dilaksanakan di PAUD dalam rangka memberikan pendidikan, pelibatan, dan pemberdayaan kepada orang tua untuk mendukung program-program pendidikan yang dilaksanakan oleh guru di sekolah.

RA Tiara Chandra Yogyakarta secara konsisten melaksanakan kegiatan parenting untuk mengajak orang tua terlibat dalam mensukseskan programpendidikan moral anak. Program parenting dilakanakan dalam bentuk pelatihan LVE minimalsekali dalam setahun dan dilanjutkan dengan parenting bulanan untuk memberikan penyegaran terhadap kegiatankegiatan yang telah disepakati.

Program parenting cukup efektif dalam menumbuhkan kesadaran orang tua untuk ikut terlibat dalam pendidikan moral anak. Orang tua yang selalu aktif melaksanakan programprogram yang telah disepakati dengan guru merasakan perubahan yang signifikat, baik untuk dirinya, dan juga buah hatinya. Sebaliknya, orang tua yang kurang aktif juga dapat dilihat dari kondisi anak yang tidak banyak mengalami perubahan dalam pengamalan nilai-nilai moral.

\section{DAFTAR PUSTAKA}

Brooks, Jane. 2011. The Process of Parenting, terj. Rahmat Fajar. Yogyakarta: Pustaka Pelajar

Creswell John W.2015. Penelitian Kualitatif dan Desain Riset. Yogyakarta: Pustaka Pelajar.
Ibung, Dian. 2009. Mengembangkan Nilai Moral pada Anak. Jakarta: PT. Alex Media Komputindo

Kementerian Pendidikan dan Kebudayaan. 2015. Kerangka Dasar dan Struktur Kurikulum 2013. Jakarta: Direktorat Pembinaan PendidikanAnak Usia Dini

Kementrian Pendidikan Nasional. (2012). Petunjuk Teknis Ujicoba Penyelenggaraan PAUD Berbasis Keluarga (Parenting) di Lembaga Pendidikan Anak Usia Dini. Jakarta: Kemendiknas (2011). Petunjuk Teknis

OrientasiTeknis Peningkatan Pemahaman Program Penguatan PAUD Berbasis Keluarga (Parenting). Jakarta: Kemendiknas

Kostelnik, dkk. 2015. Kurikulum Pendidikan Anak Usia Dini Berbasis Perkembangan Anak. Jakarta: Prenada Media Group

Lickona, Thomas. (2013). Educating for Character, terj. Juma Abdu Wamaungo. Jakarta: BumiAksara.

Mega Silvia Retnaningty dan Pramesti Pradna Paramitha (2015) Jurnal Psikologi Pendidikan dan Perkembangan, Volume 4 Nomor 1 Tahun 2015

Sugiyono. 2016. Metode Penelitian Pendidikan: Pendekatan Kuantitatif, Kualitatif dan $R \& D$. Bandung: Alfabeta.

Tillman, Diane. 2004. Living Values: An Educational Program, Living Values Activities for Children Ages 3-7. Jakarta: Grasindo 


\section{LAMPIRAN}

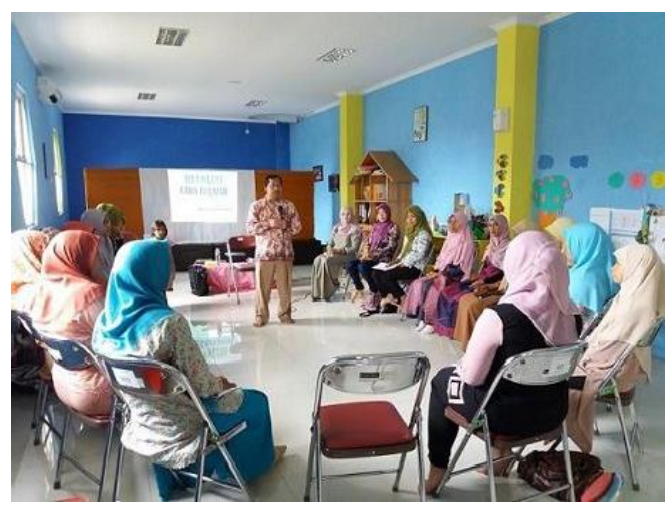

Gambar 1 Pelatihan LVE

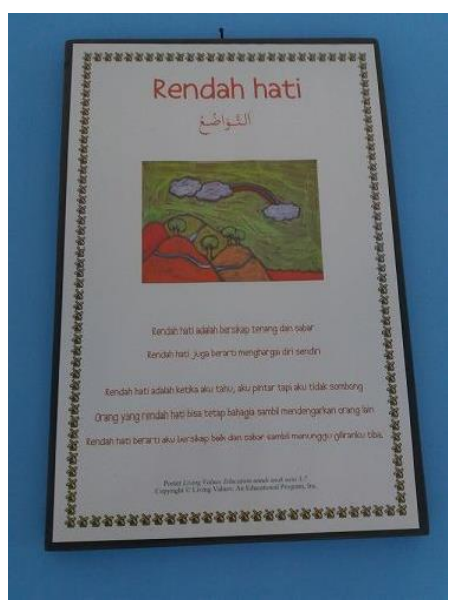

Gambar 2 Contoh Poster / Kartu Anak Hebat

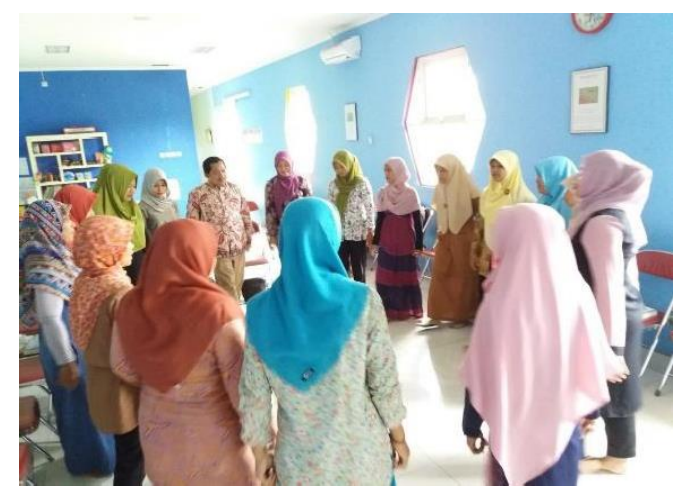

Gambar 3 Salah satu kegiatan dalam pelatihan LVE

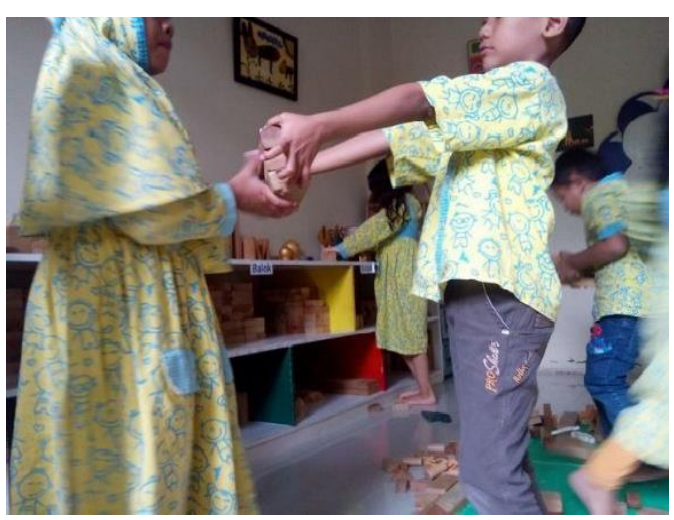

Gambar 4 Contoh nilai Kerjasama

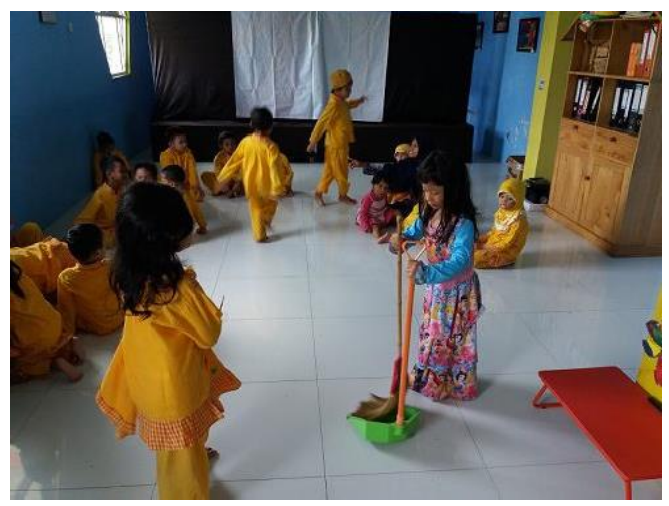

Gambar 5 Contoh nilai Tanggung Jawab

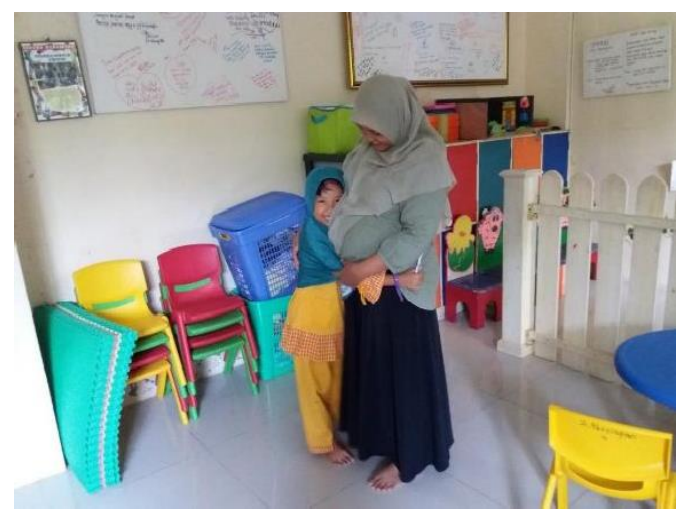

Gambar 6 Contoh nilai Kasih Sayang 